\title{
Beyond Enterprise: The Effect of Linkages and Partnerships Resource Mobilisation Structure on the Financial Sustainability of Universities in Kenya
}

\author{
Janet A. Chumba \\ Department of Business Administration, Jomo Kenyatta University of Agriculture and Technology, Kenya. \\ P.O. Box 62000 - 00200, Nairobi, Kenya. \\ *E-mail of corresponding author: janetchumba@yahoo.com
}

\begin{abstract}
The declining funding for public universities and reduced investment in private university education in Kenya is forcing the financial managers in these institutions to explore different resource mobilization structures to guarantee their financial sustainability. Universities in the $21^{\text {st }}$ century have adopted various resource mobilization structures for financial stability. However, it is not certain which of the structures ensure financial sustainability. One of the key available sources of revenue has been in linkages and partnerships, specifically public-private partnerships, and academic collaborations, to mobilize resources for infrastructure development and to support research and academic programme. This paper goes beyond the entrepreneurial profit-oriented mindset in raising resources for higher education institutions and analyses the effect of linkages and partnership structures for the financial sustainability of universities in Kenya. The study is anchored on knowledge based theory which supports research activities undertaken by universities through strategic alliances with the aim of generating new knowledge that would improve the welfare of the society at large. The paper uses the descriptive and cross-sectional corelational survey design, with the study population comprising 71 universities in Kenya. The target respondents were the 71 finance officers drawn from each of the 71 universities $(n=71)$, who were providing information as to whether their universities had entered strategic alliances and what these were supporting). The findings show that most universities had entered into public-private partnerships $(M=3.27)$ with a view to fiscal sustainability, more than those that had cultivated strategic alliances for academic and research goals $(M=2.21)$. These results illuminate the financial potential of linkages and partnerships as a viable resource mobilization structure on which to anchor the financial sustainability of universities in Kenya, with both the national and county governments, the industry, and with other universities globally.
\end{abstract}

Keywords: Resource mobilization, Partnerships, Linkages, Funding, Universities, Higher education, Financial sustainability

DOI: $10.7176 / \mathrm{JESD} / 11-20-15$

Publication date:October $31^{\text {st }} 2020$

\section{Introduction}

The declining funding for institutions of higher education across the world and even in Kenya, and the resultant strategies through which these institutions strive to raise income continues to be documented (Longden, 2001; Wangenge-Ouma, 2008; Abankina, Vynaryk \& Filatova, 2017; CPS Research International, 2018; Chumba, Muturi $\&$ Oluoch, 2019). However, there appears to be an increasing view in the business and economic world for universities to be enterprising and to raise their own income (Odhiambo, 2011). This persistent and consistent focus on what qualifies as income-generating avenues for universities, have come at a huge cost to the pursuit of the core mission of the universities as Mutula (2001) and Odhiambo (2011) illustrate, effectively showing that universities concentrate on making money, and forget that their core mission is anchored in academic and research pursuits. Even as they raise their own revenue through entrepreneurial activities including setting up consultancy units, the income is mainly focused on incentivizing the staff doing these jobs, and is, in most cases, insufficient to help ease the financial pressure (Kavulya, 2006; Chumba, Muturi \& Oluoch, 2019).

This paper argues that the focus on what Odhiambo (2011) cites as academic capitalism - and on that which Chumba, Muturi \& Oluoch (2019) referred to as investment and consultancy resource mobilization structuresto the detriment of the key goals of the universities ultimately affects the quality of higher education. Therefore, this paper introduces linkages and partnerships specifically, the public-private partnerships and academic collaboration, to mobilise resources for infrastructure development, research, and for running academic 
programmes, as an alternative resource mobilization structure.

For purposes of this paper, linkages are construed as the whole spectrum of relationships and interactions which universities, or departments within universities, enter into with a goal of not only promoting the exchange of knowledge, but also generate the social, financial and cultural impetus to boost the quality of higher education (Vasi \& King, 2012). This paper also deploys the word partnership to refer to formal arrangements between universities on one hand, and other corporate associates, be it other universities, local or national governments, private enterprises, the civil society parties and even non-governmental organizations to come up with projects that buttress the academic and research proclivities of universities, while at the same time, fulfilling the research and socio-economic goals on the respective allies (Kinser \& Green, 2009). This paper goes beyond the entrepreneurial profit-oriented mindset in raising resources for higher education institutions and analyses the effect of linkages and partnerships structures for the financial sustainability of universities in Kenya.

It is the position of this paper that linkages and partnerships need not only be restricted to the public-private realm, essentially between public universities and players in the private sector or vice versa, but also extended to cover the partnerships between universities in Kenya, whether public and private, and the foreign public and private partners. Also, academic collaborations remain a top priority, not only towards achieving the research and academic ends, but also with a focus towards improving the overall social, economic and cultural goals of the Kenyan society - essentially addressing the priorities identified in the sustainable development goals, especially Goal 4 on "inclusive and equitable quality education and promote lifelong learning opportunities for all" (UN, 2015). What must not be forgotten in reading this paper is that it is about how linkages and partnership can be deployed as resource mobilization structures, and how their application affects the financial sustainability of universities in Kenya. As Vasi \& King (2012) explain, when it comes to resource mobilization, it is not simply about new resources, but also about optimizing the existing resources to extract as much value as possible.

\subsection{Statement of the problem}

After the Kenya government made a policy decision while under pressure from the World Bank to reduce the funding towards university education in favour of other development priorities, many scholars continue to frame the financial constraints within universities as a funding problem (Psacharopoulos \& Woodhall, 1985; Kavulya, 2006; Wangenge-Ouma (2008); Gichuhi, 2015; CPS Research International 2018). As the public funding declined at a time when enrolment numbers were increasing, many universities felt the financial pressure, and given the capitalist environment with its colonial roots, many were pushed to seek ways to make money from the market. This involved setting up business entities, going into agri-business, and even opening up the universities to selfsponsored students in order to generate the much-needed revenue to run university operations (Mutula, 2001, Wainaina \& Mwangi, 2006; Wangenge-Ouma, 2008 and 2012). The goal was that as these universities generated additional income, they would plough the profits to cover the shortfall arising from the government's withdrawal of funding. This did not happen, and as Kavulya (2006) notes, the profits were used to make the business more profitable, while the utility of the public universities as public goods suffered. Meanwhile, private universities thrived as they exploited the demand in university education thanks to the deteriorating physical facilities in public universities; the rigidity of the courses provided which were unresponsive to the rising needs of a private business world, thanks largely to the policies around privatization of public institutions (Oketch, 2003 \& Munene, 2009).

This paper goes beyond the entrepreneurial profit-oriented mindset in raising resources for higher education institutions and analyses the effect of linkages and partnerships structures for the financial sustainability of universities in Kenya. It focuses on linkages and partnerships, because, while these provide the much-needed revenue, expertise and even create room for the pursuit of innovative research and academic projects, there's no added pressure on the universities to generate profits out of these (Kinser \& Green, 2009; Chiteng Kot, 2014). Although some partnerships may have a profit motive, this paper takes the position that the potential of linkages and partnerships between universities on one side, and governments, public institutions, corporates communities, the civil society and even foreign universities can bring in more financial resources, and guarantee financial sustainability (Timmermans \& Bouman, 2008; Chiteng Kot, 2014). Again, for emphasis, this paper is about resource mobilization using linkages and partnerships, not funding per se, but the element of fiscal sustainability has to inform these collaborations.

\subsection{Study purpose}

The main purpose of this study is to find out the effect of linkages and partnerships on the financial sustainability of universities in Kenya. By examining this aspect, this paper illuminates the fact that academic collaborations, linkages and partnerships, including with the private sector and foreign players are key in not only improving the quality of higher education in Africa, but also in creating a fiscally sustainable environment. While linkages and 
partnerships have existed in Africa since the pre-independence period and continued through the postindependence period, their contribution to the financial sustainability of universities in Kenya has rarely been studied. Therefore, this paper lays the foundation by examining aspects of linkages and partnership and how these affect the financial sustainability of universities, with the hope that future studies will explore viable models to guarantee financial sustainability outside the enduring legacy of colonialism and the North-South imbalance amplified through globalisation that continues to define these linkages and partnerships. It also tries to introduce a paradigm shift to university managers that funding shortfalls need not only be dealt with through increasing fees, getting into income-generating activities through investment and consultancy, or on donors, but also by using strategic linkages and partnerships in research and academic programmes.

\section{Literature Review: Conceptual Framework}

Kenya's first public university, the University of Nairobi started off in 1956 as the Royal Technical College, with a charter signed by the then colonial governor Philip Euen Mitchell focused on providing "vocational training" in "engineering, in commerce and accountancy, in agricultural, medical and veterinary laboratory science, in industry, in domestic science, in arts and crafts, in sanitary science, in pharmacy, and in such other vocations as may be desirable for the sound economic advancement of the East African Territories". This paper goes back to that history because it yields to the observation made by Oketch (2003) that universities in Kenya were designed around fulfilling the labour needs of the colonial bureaucracy, and later the post-colonial State. Similarly, Edmondson et al. (2012) argues that the university-industry collaboration has existed for centuries, only that as the global knowledge economy expands, there is a push for more strategic linkages and partnerships. These need not be only in-country but also target foreign institutions, to assist in the transfer and exchange of knowledge between the Global North and the Global South, and between universities in countries in the Global South (Mihyo, 2013). Essentially, it is about harnessing useful knowledge wherever it can be found, and extracting value, including financial value from it, for the financial sustainability of universities. That said, it must be remembered that the contribution of universities varies depending on the country context, that is, universities contribute differently in developing and developed countries as Serbanica, Constantin \& Dragan (2015) helpfully note.

\subsection{Knowledge-based Theory}

It is difficult to discuss strategic linkages and partnerships at the university level, especially the public-private partnerships and academic collaborations without revisiting the knowledge-based theory espoused by Grant (1996). The key cogs that make this theory relevant is the basic principle that when it comes to universities, and the importance of their academic and research goals to the knowledge economy, then the value that the public institutions, the private sector, civil society organisations and even foreign universities or governments is in the resident knowledge within those universities (Sveiby, 2001). To understand how the knowledge-based theory explains these linkages and partnerships, one has to remember the words of Sveiby (2001) as he argued that knowledge within firms generated "internal structures" comprising "patents, concepts, models, and computer and administrative systems." It is this knowledge, that when exploited gives "tangible structures such as machinery and tools, and intangible structures such as better processes and new designs for products."

For Kenyan universities interested in local and international linkages and partnerships, this theory came to life when two universities exploited their knowledge to a great extent, especially in executing the compound partnership with private-sector players and then linking up with the government to assemble laptops in the furtherance of the national policy to provide tablets to Standard One at a colossal Sh19 billion (Kajilwa, 2016). The project involved Moi University and the Jomo Kenyatta University of Agriculture and Technology. Also, Moi University has acquired Rivatex to provide textiles (really an investment and therefore entrepreneurial), but it is the link with government for fabrics for uniforms for security forces, schools and hospitals that shine more light on the power of linkages and partnerships - again in line with the Big 4 Agenda to grow manufacturing (Kimuge \& Kiprotich, 2019). What needs to be remembered, is that for universities to form viable strategic linkages and partnerships, there has to be a knowledge imbalance in the university-industry ecosystem, which then creates a demand for the knowledge resident in universities, and a need for the universities to find avenues to test their knowledge, or to bring that knowledge to life, while the industry also has to have the gap for that knowledge, whether in seeking new designs, efficient processes or other profitable pursuits (Grant, 1996, Sveiby, 2001, Edmondson et al., 2012; Mihyo, 2013; Chiteng Kot, 2014).

\subsection{Understanding linkages and partnerships in universities}

Edmondson et al. (2012) noted that universities and industry have been partnering and collaborating for over a century, but the rise of a global knowledge economy has spawned strategic partnerships that go beyond the 
traditional funding to collaborations around standalone research projects. Ayoubi (2012) also details how university-industry partnerships, and university-university partnerships, and linkages with public and private sectors, are beneficial to the overall raison d'etre for universities. These partnerships have had a positive impact on financial sustainability of the learning institutions. In addressing linkages and partnerships especially for universities in Africa, this paper turned to the important work of Chiteng Kot (2014) who revisited the foundations of the North-South academic collaborations. In his paper on Stakeholder participation in international higher education partnerships: results of a survey of two sub-Saharan African universities, Chiteng Kot (2014) cites studies which show an increase in partnerships between the foreign and African universities and predicts that this is going to increase because such linkages and partnerships are seen as paths to development.

"Governments and international organizations recognize that, without a strong higher education system, it is impossible to decrease the knowledge and technology gap between the developed and developing countries, and address challenges to socio-economic development... Many believe that partnerships, along with the subsequent sharing of knowledge and expertise, can foster research and help build the institutional and human capacity needed for higher education to play its role as an engine for socio-economic development. (Chiteng Kot, 2014, p255)"

While his study covered Tanzania and the Democratic Republic of Congo, two of African countries that are still ranked as "least developed countries" by the World Bank, his prognosis about the global recognition on the power of higher education in the development of African nations has its supporters in Kubler (2005). These linkages and partnerships can therefore be construed as an extension of the international development cooperation, with the results being collaborations in research, institutional development, capacity building, and simply academic networking (Chiteng Kot, 2014). This is an observation that was made earlier by Obamba and Mwema (2009) in which they cited these international linkages and partnerships as " most productive framework for reinvigorating and strengthening research capacity within sub-Saharan Africa universities" p21.

Linkages and partnerships come in many forms. These range from collaborative teaching and curriculum development, joint research, joint conferences, seminars and even workshops, academic staff and student exchanges, training including staff training, community development projects, student placement and/or internships, and even professional development courses (Samoff \& Carrol, 2004: Chiteng Kot, 2014). Timmermans \& Bouman (2008) also observe that universities can partner with the communities to provide services such as accommodation, one-time services, and short courses, that not only boost the revenues of the universities, but also help these institutions of higher learning to earn some social capital through that collaboration, while at the same time, alleviating the pressure on facilities. But as Ayoubi (2012) explains, when it comes to forming partnerships, universities have to consider the demand factors, their priorities and that of partners, and with regard to international linkages and partnerships, the universities have to pick partners who are "the best in their own country", one with sufficient resources and capacity to add value academic and development value to the partnership.

In Kenya, university partnerships continue to persist, not just with the private sector and with government as mentioned earlier in this paper, but also between Kenyan universities and foreign universities. Further, Kenyan universities have become innovative at coming up with research and academic projects that not only involve other universities, but also the government and players in the private sector (See Kajilwa, 2016). For example, Moi University has the Academic Model Providing Access to Healthcare project (AMPATH) which it is implementing jointly with US institutions of higher learning Indiana University and Purdue University and even the government of Kenya, essentially fostering academic and research collaborations, knowledge transfer and staff exchange (Koehn and Obamba, 2014). The university of Nairobi in Kenya too collaborated with Flemish universities under the VLIR-UOS (acronym for University Development Cooperation) in partnership worth $€ 6.8$ million (KSh756 million) in investments and scholarships (de Nooijer and Abagi, 2009). The partnership and linkages were mainly in boosting the research and teaching infrastructure, staff development with a focus on rural health, marine sciences and a computer network to cover the university, subsequently leading to a digital library, open learning and a strengthened computer science. There are many more examples of partnerships and linkages that Kenyan universities have forged with the public and private sector, local and foreign universities, communities, and other stakeholders in the civil society to pursue sustainable development goals, but looking at all those is beyond the scope of this paper.

At this point, this paper will lean on the useful prescription of the Africa Unit of the Association of Commonwealth Universities (ACU) that effective education partnerships have to bring mutual benefits to the parties involved. While these linkages and partnerships need not yield symmetrical benefits to the educational institutions and the stakeholders, there has to be a shared ownership of the projects or programmes with the foundational principles of transparency, reciprocity, trust and respect, coupled with joint decision-making, and an appreciation of the cultural 
contexts of the respective partners (Africa Unit, 2010). But what must not be forgotten is that as linkages and partnerships grow, the terms and expectations evolve, and therefore, for these to succeed, there has to be an agility and dynamism together with open and clear communication in their implementation and execution. To conclude this section, we recapitulate back to Chiteng Kot (2014) who said that it is not enough for universities to show memoranda of understanding as proof of linkages and partnerships, because, most of these are more often "nothing more than good intentions" (p267). Effective linkages and partnerships need not be symbolic, but should have real activities, projects and programmes being implemented, and for the purposes of this paper on financial sustainability and using linkages and partnerships as a resource mobilization structure, these also need to have a financial incentive among the partners involved.

\section{Research Methodology}

This paper draws from the descriptive cross-sectional correlational survey research design, which as Yin (2013) explained, is the best suited in unpacking the research problem and achieving the objectives. As Mugenda \& Mugenda (2003) argue, the correlational approach helps to determine the degree of relationships between quantifiable variables, in this case, the linkages and partnerships structure of financial resource mobilisation and its effect on the financial sustainability of Kenyan universities.

The study population comprised all 71 universities in Kenya. The sampling frame consisted of the list of universities available at the Commission of University Education (CUE) as at December 31, 2018. The total number of universities in Kenya is low and can all be easily accessed. This study therefore targeted the 71 finance officers as the respondents effectively adopting a census sampling technique.

\subsection{Data Collection}

This paper sought primary and secondary data. The collection of primary data was done using structured questionnaires with open-ended questions. The justification for questionnaires is that they allowed the collection of data in a uniform manner from all the finance officers in the 71 universities within the limited period. The questionnaire was part of a larger study on the financial resource mobilisation structures and the financial sustainability (Chumba, Muturi \& Oluoch, forthcoming), with the specific data on linkages and partnerships resource mobilisation structure sought in one of the sections. For secondary data, this study used data collection sheets to curate data obtained from the financial statements of the public universities, and from the reports and journals at the Ministry of Devolution and Planning. This information is gathered annually because financial statements are prepared every fiscal year. The secondary data was germane for panel data analysis.

\subsection{Data Analysis}

The collected data was analysed using the Statistical Package for Social Scientists (SPSS, version 24.0), but first, all the questionnaires were checked for completeness and thereafter the available responses were coded to facilitate data entry. Using Cronbach's Alpha, the reliability tests were done. Further, during the analysis, descriptive statistics reports were developed representing the various research items. A Five-point Likert scale - with 1 as the minimum score and 5 as the maximum - was used to assess the means and percentage responses to the items in the questionnaire. It is at this point that cross-tabulation was used to measure the relationship between two categorical variables, leaning on the wisdom of Babbie (2011) that cross tabulations are an appropriate statistical test to determine the independent and dependent categorical variables. For this paper, the statistical significance of relationships was ascertained using the arson chi-square values and associated probability values (P-values).

Besides, to establish the extent of the linear relationship between the linkages and partnerships resource mobilisation structure and the financial sustainability of the Kenyan universities, multiple linear regression analysis was conducted. The model used in this study is:

$$
Y_{i}=\beta_{0}+\beta_{1} X_{1}+\varepsilon Y_{i}=\beta_{0}+\beta_{1} X_{1}+\varepsilon
$$

Where: $\boldsymbol{Y}_{\boldsymbol{i t}} \boldsymbol{Y}_{\boldsymbol{i t}}$ - Financial Sustainability of the Universities

$\mathbf{B}_{0}$ - Constant term of the regression model

$\mathbf{B}_{1}$ - Regression coefficient for Linkages and partnerships structure

$\mathbf{X}_{\mathbf{1}}$ - Linkages and partnerships structure

$\boldsymbol{\varepsilon}_{\boldsymbol{i t}} \boldsymbol{\varepsilon}_{\boldsymbol{i t}}$ Random error term

$i$ and $t$ are indices for panel variables (Universities) and time variables respectively.

The model summary has the coefficient of determination showing the percentage of variations in the dependent 
variable resulting from the variations in the independent variables. This is followed by an Analysis of Variance (ANOVA) table covering both the model and the residuals and a table summarising the regression coefficients of the variables of the study, the computed values of the t-statistic and a determination of the statistical significance in comparison to the baseline significance level.

\section{Results}

\subsection{Descriptive statistics for the linkages and partnerships resource mobilisation structure}

Linkages and partnerships was identified as one of the most important resource mobilization strategies and as summarized in the table 4.11, the statement that the universities had entered into public-private partnerships had the highest mean, $M=3.27$, indicating that this structure was common in most of the universities that participated in the study especially in comparison with the fact that universities had entered into strategic alliances with the various stakeholders, $M=2.21$. This finding is in line with Edmondson et al. (2012) who noted that universities and industry have been collaborating for over a century, but the rise of a global knowledge economy has intensified the need for strategic partnerships that go beyond the traditional funding of discrete research projects. It also noted that world class research universities are at the forefront of pioneering such partnerships. These partnerships have had a positive impact on financial sustainability of the learning institutions.

Table 1: Linkages and partnership structure

\begin{tabular}{lll}
\hline Statement & Mean & SD \\
\hline The University has entered into strategic alliances with various stakeholders & 2.21 & 1.1328 \\
The University has entered into public private partnerships & 3.27 & 1.5396 \\
Our organization have well stipulated partnerships policies & 2.27 & 1.0096 \\
\hline
\end{tabular}

On the relationship between linkages and partnership structure, the findings summarized in the table above clearly show that the fact that universities had entered in public-private partnerships had the highest standard deviation, $S D=1.5396$ while the statement that the universities had entered into strategic alliances with various stakeholders yielded the least, $S D=1.1328$ indicating more consistency of the opinion from the respondents on this aspect.

Further, the study findings summarized in the table below indicated that public private had the highest arithmetic mean, $M=2.76$ followed by academic exchange programs and trainings, $M=2.1$.

Table 2: Descriptive statistics on linkages and partnerships

\begin{tabular}{lll}
\hline Statement & Mean & SD \\
\hline Public private partnerships & 2.76 & 1.3252 \\
Academic exchange programs & 2.1 & 1.0022 \\
Academic trainings & 1.62 & 0.4889 \\
\hline
\end{tabular}

With regard to the variability of the statements given by the respondents, the table above clearly indicates that academic trainings had a least value of, $S D=0.4889$ indicating more consistency in comparison to public-private partnerships at $S D=1.32$ indicating high variability on this aspect. This means that academic exchange programme is a more popular structure in universities as compared to public private partnerships.

\subsection{Effect of linkages and partnership resource mobilization structure on financial sustainability of universities in Kenya}

This study sought to establish the effect of linkages and partnerships on financial sustainability of selected universities in Kenya. After using a simple linear regression model the findings are summarized in the table below provide both the model summary as well as ANOVA that was meant to test whether ratio of variations caused by the model and those of the residual were statistically significant from the computation of the F-statistic. 
Table 3: Model Summary and ANOVA Table

\begin{tabular}{lllll}
\hline Source & SS & Df & MS & $\begin{array}{l}\text { Number of obs }=71 \\
\text { F }(1,69)=620.88\end{array}$ \\
\hline Model & 13.4112472 & 1 & 13.4112472 & Prob $>\mathrm{F}=0$ \\
Residual & 1.49042868 & 69 & 0.021600416 & R-squared $=0.9$ \\
& & & Adj R-squared $=0.8985$ \\
Total & 14.9016759 & 70 & 0.212881084 & Root MSE $=0.14697$ \\
\hline
\end{tabular}

The result of the goodness of fit test above indicate that the value of R-squared $=0.9$, which means that $90 \%$ of variations in the dependent variable were caused by variations in the independent variables, while $10 \%$ were caused by other factors. In checking for the goodness of fit of the model, it can be seen that the p-value for the Fstatistic was below 0.05 indicating that the model was fit as a predictive model for the relationship between linkages and partnerships and financial sustainability. This finding concurred with Edmondson et al. (2012) who indicated that world class research universities are at the forefront of pioneering such partnerships. These partnerships have had a positive impact in financial sustainability of the learning institutions. This was followed by a summary of the regression coefficients in the table below:

Table 4: Linkages and Partnership Resource Regression Coefficients Table

\begin{tabular}{lllllll}
\hline Financial Sustainability & Coef. & Std. Err. & $\mathrm{t}$ & $\mathrm{P}>|\mathrm{t}|$ & {$[95 \%$ Conf. Interval] } \\
\hline Linkages and partnership structure & 0.52842 & 0.02120 & 24.9 & 0.00 & 0.48612 & 0.570735 \\
cons & 0.52006 & 0.03888 & 13.3 & 0.00 & 0.44248 & 0.597631 \\
\hline
\end{tabular}

From the results of the regression table 4.26 for linkages and partnerships above it is clear that this resource mobilization structure had a statistically significant regression coefficient and the value of regression coefficient was $\beta_{5}=0.52 \beta_{5}=0.52$, thus indicating that a unit increase in linkages and partnership structure was associated with 0.52 increase in financial sustainability of the selected universities.

\section{Conclusion}

This paper takes the position that the potential of linkages and partnerships between universities on one side, and governments, public institutions, corporates communities, the civil society and even foreign universities can bring in more financial resources, and guarantee financial sustainability (Timmermans \& Bouman, 2008; Chiteng Kot, 2014). Again, for emphasis, this paper is about resource mobilization using linkages and partnerships, not funding per se, but the element of fiscal sustainability has to inform these collaborations. Similarly, Edmondson et al. (2012) argues that the university-industry collaboration has existed for centuries, only that as the global knowledge economy expands, there is a push for more strategic linkages and partnerships. These need not be only in-country but also target foreign institutions, to assist in the transfer and exchange of knowledge between the Global North and the Global South, and between universities and stakeholdersin countries in the Global South (Mihyo, 2013).

Essentially, it is about harnessing useful knowledge wherever it can be found, and extracting value, including financial value from it, for the financial sustainability of universities. That said, it must be remembered that the contribution of universities varies depending on the country context, that is, universities contribute differently in developing and developed countries as Serbanica, Constantin \& Dragan (2015) helpfully note. Most universities have entered into public partnership private partnerships. Strategic alliances with various stakeholders have an influence on sustainability of universities. Research should focus on areas that have direct impact on society with a view of enhancing financial sustainability. But what must not be forgotten is that as linkages and partnerships grow, the terms and expectations evolve, and therefore, for these to succeed, there has to be an agility and dynamism together with open and clear communication in their implementation and execution.

To conclude, we recapitulate back to Chiteng Kot (2014) who said that it is not enough for universities to show memoranda of understanding as proof of linkages and partnerships, because, most of these are more often "nothing more than good intentions" (p267). Effective linkages and partnerships need not be symbolic, but should have real activities, projects and programmes being implemented, and for the purposes of this paper on financial sustainability and using linkages and partnerships as a resource mobilization structure, these also need to have a 
financial incentive among the partners involved.

\section{References}

Africa Unit. (2010). Good practices in educational partnerships guide: UK-Africa higher and further education partnerships. London: The Africa Unit, Association of Commonwealth Universities.

Altbach, P. G. (2010). The realities of mass higher education in a globalised world. Higher education in a global society, 25-41.

Amponsah, E. B., \& Onuoha, L. N. (2013).The performance and challenges of private universities in Ghana and Nigeria. International Journal of Business and Social Science, 4(5).

Amui, L. B. L., Jabbour, C. J. C., de Sousa Jabbour, A. B. L., \& Kannan, D. (2017). Sustainability as a dynamic organizational capability: a systematic review and a future agenda toward a sustainable transition. Journal of Cleaner Production, 142, 308-322.

Anderson, W. A., Banerjee, U., Drennan, C. L., Elgin, S. C., R., Epstein, I. R., Handelsman, J., \& Strobel, S. A. (2011). Changing the culture of science education at research universities. Science, 331(6014), 152-153.

Ayoubi, R.M. (2012) A model of re-evaluating international partnerships in universities: a UK example. European Journal of Higher Education, 3(2), 220-234, DOI:10.1080/21568235.2012.746421

Babbie, E. R. (2012). Brooks/Cole Empowerment Series: Essential research methods for social work. Cengage Learning.

Bacq, S., Ofstein, L. F., Kickul, J. R., \& Gundry, L. K. (2015). Bricolage in social entrepreneurship: How creative resource mobilization fosters greater social impact. The International Journal of Entrepreneurship and Innovation, 16(4), 283-289.

Bai, X., Salim, R., \& Bloch, H. (2019). Environmental Efficiency of Apple Production in China: A Translog Stochastic Frontier Analysis. Agricultural and Resource Economics Review, 1-22.

Barrow, L., \& Rouse, C. E. (2016). Financial incentives and educational investment: The impact of performancebased scholarships on student time use. Education Finance and Policy.

Belkania, D., \& Karimov, M. (2018). An Empirical Examination of the Export-Led Growth Theory Regarding Georgia. European Journal of Marketing and Economics, 1(3), 88-96.

Bloom, D. E., Canning, D., \& Chan, K. (2015).Higher Education and Poverty in SubSaharan Africa. International Higher Education, (45).

Bogan, V. L. (2008). Microfinance institutions: Does capital structure matter?

Bomberg, E., \& McEwen, N. (2012).Mobilizing community energy. Energy Policy, 51, 435-444.

Bryman, A. (2012). Understanding research for social policy and social work: themes, methods and approaches. Policy Press.

Bunoti, S. (2011, June). The quality of higher education in developing countries needs professional support. In 22nd International Conference on Higher Education. Retrieved from http://www. intconfhighered. org/FINAL\% 20Sarah\% 20Bunoti. pdf.

Chiteng Kot, F. (2014). Stakeholder participation in international higher education partnerships: results of a survey of two sub-Saharan African universities. Tertiary Education and Management, 20(3), 252-272. doi:10.1080/13583883.2014.936484

Chumba, J. A., Muturi, W., \& Oluoch, J. O. (2019). Effect of financial investment strategies on the financial sustainability of universities in Kenya. International Academic Journal of Economics and Finance, 3(3), 37-49.

Chumba, J.A., Muturi, W., \& Oluoch, J. O. (Forthcoming). Financial Resource Mobilization Structures and Financial Sustainability of Universities in Kenya. PhD Dissertation

Cooper, J. W., \&Schindler, T. (2008). Approaches to Scientific Research Design: Qualitative and Quantitative work methods.

Creswell, J. W. (2013). Research design: Qualitative, quantitative, and mixed methods approach. Sage publications. Creswell, J. W., \& Clark, V. L. P. (2007). Designing and conducting mixed methods research.

de Nooijer, Paul, and Okwach Abagi. 2009. Final Evaluation of the IUC Partner Program with the University of 


\section{Nairobi (UoN), Kenya. Gent: VLIR-UOS.}

De Silva, M., Howells, J., \& Meyer, M. (2018). Innovation intermediaries and collaboration: Knowledge-based practices and internal value creation. Research Policy, 47(1), 70-87.

Dikko, M. (2016). Establishing construct validity and reliability: Pilot testing of a qualitative interview for research in Takaful (Islamic insurance). The Qualitative Report, 21(3), 521-528.

Drucker, J., \& Goldstein, H. (2007). Assessing the regional economic development impacts of universities: A review of current approaches. International regional science review, 30(1), 20-46.

Edmondson, G., Valigra, L., Kenward, M., Hudson, R. L., \& Belfield, H. (2012). Making Industry-University Partnerships Work. Lessons from Successful Collaborations. Science Business Innovation Board.

Eisenhardt, K. M., \& Santos, F. M. (2002). Knowledge-based view: A new theory of structure . Handbook of structure and management, 1(139-164).

Geuna, A., \& Nesta, L. J. (2006). University patenting and its effects on academic research: The emerging European evidence. Research Policy, 35(6), 790-807.

Godina, R., \& Matias, J. C. (2018, March). Improvement of the statistical process control through an enhanced test of normality. In 2018 7th International Conference on Industrial Technology and Management (ICITM) (pp. 17-21). IEEE.

Grant, R. M. (1996). Toward a knowledge-based theory of the firm. Strategic Management Journal, 17(S2), 109122.

Gudo, C. O., Olel, M. A., \& Oanda, I. O. (2011). University expansion in Kenya and issues of quality education: Challenges and opportunities. International Journal of Business and Social Science, 2(20).

Kajilwa, G. (2016). First batch of school laptops arrive in Nairobi, all Class One pupils to have devices by December. The Standard. Retrieved from https://www.standardmedia.co.ke/article/2000210973/first-batch-ofschool-laptops-arrive-in-nairobi-all-class-one-pupils-to-have-devices-by-december

Kaul, M. (2015). Genres of Inquiry in Design-Science Research: Justification and Evaluation of Knowledge Production. MIS Quarterly, 39(3), 541-564.

Kimuge, S., \& Kiprotich, P. (2019, June 20). Uhuru to commission a revamped Rivatex factory Nation. Retrieved from https://www.nation.co.ke/counties/uasingishu/All-set-for-Uhuru-visit-at-Rivatex/1183334-5164958knqxs8z/index.html

Kinuthia, W. (2009). Educational development in Kenya and the role of information and communication technology. International Journal of Education and development using ICT, 5(2).

Kothari, C. R. (2004). Research methodology: Methods and Techniques. New Age

Kubler, J. (2005). African and UK university partnerships. London: Association of Commonwealth Universities.

Kwiek, M. (2016). De-privatisation in higher education: A conceptual approach. Higher Education, 1-23.

Lawson, B., \& Samson, D. (2001).Developing innovation capability in organizations: a dynamic capabilities approach. International journal of innovation management, 5(03), 377-400.

Lee, C., Lee, K., \& Pennings, J. M. (2013).Internal Capabilities, External Linkages, and Performance: A Study on Technology-based Korean Ventures draft 13.

Loebbecke, C., van Fenema, P. C., \& Powell, P. (2016). Managing inter-organizational knowledge sharing. The Journal of Strategic Information Systems, 25(1), 4-14.

Manuh, T., Gariba, S., \& Budu, J. (2007). Change and transformation in Ghana's publicly funded universities. Partnership for Higher Education in Africa. Oxford, UK: James Currey and Accra, Ghana: Woeli Publishing Services.

Mihyo, B. P. (2013) University-industry linkages and knowledge creation in Eastern and Southern Africa: some prospects and challenges, Africa Review, 5(1), 43-60, DOI: 10.1080/09744053.2013.832066

Mugenda, O. M., \& Mugenda, A. G. (2012). Research methods dictionary.

Mungai R., \& Wanja, I. M. B. (2011, June). The performance of university-industry collaborations: empirical evidence from the Netherlands. In DRUID 2011 Summer Conference, held (pp. 15-7).

Munene, I.I. (2009). Anticipated developments: East Africa's private universities and privatisation of public 
universities in the global context, Africa Education Review, 6(2), 254-268, DOI: 10.1080/18146620903274571

Nyangau, J. Z. (2014). Higher Education as an Instrument of Economic Growth in Kenya. FIRE: Forum for International Research in Education, 1(1). http://dx.doi.org/10.18275/fire201401011006

Obamba, M. O., \& Mwema, J. K. (2009). Symmetry and asymmetry: New contours, paradigms, and politics in African academic partnerships. Higher Education Policy, 22, 349-371.

Oketch, O. M. (2003) The Growth of Private University Education in Kenya: The Promise and Challenge, Peabody Journal of Education, 78(2), 18-40, DOI: 10.1207/ S15327930PJE7802_02

Omondi, M. M., \& Muturi, W. (2013). Factors affecting the financial performance of listed companies at the Nairobi Securities Exchange in Kenya.

Orozco-Quintero, A., \& Berkes, F. (2010). Role of linkages and diversity of partnerships in a Mexican communitybased forest enterprise. Journal of Enterprising Communities: People and Places in the Global Economy, 4(2), $148-161$

Psacharopoulos, G., \& Woodhall, M. (1993). Education for development. Oxford: Oxford University Press.

Parker, L. D. (2013). Contemporary university strategizing: the financial imperative. Financial Accountability \& Management, 29(1), 1-25.

Patz, R., \& Goetz, K. H. (2017, June). Resource mobilization strategies and administrative structures in the United Nations system. In International Conference on Public Policy (ICPP), Singapore (pp. 28-30).

Perkmann, M., King, Z., \& Pavelin, S. (2011). Engaging excellence? Effects of faculty quality on university engagement with industry. Research Policy, 40(4), 539-552.

Prasad, P. K. (2014). Factors influencing quality of education: A case study of eighth grade students' mathematics learning achievement in Nepal (Doctoral dissertation, Nagoya University).

Reeves, T. C., Herrington, J., \& Oliver, R. (2015). Design research: A socially responsible approach to instructional technology research in higher education. Journal of Computing in Higher Education, 16(2), 96.

Robertson, S. L. (2010). Challenges Facing Universities in a Globalizing World, published by the Centre for Globalization, Education and Societies, University of Bristol, Bristol BS8 1JA, UK: http://susanleerobertson.com/publications/Accessed on 26th January, 2017.

Robinson, D. T., \& Sensoy, B. A. (2013). Do private equity fund managers earn their fees? Compensation, ownership, and cash flow performance. Review of Financial Studies, 26(11), 2760-2797.

Samoff, J., \& Carrol, B. (2004). The promise of partnership and continuities of dependence: External support to higher education in Africa. African Studies Review, 47, 67-199. Retrieved from rom www.jstor.org/stable/1514799

Sanyal, B. C., \& Johnstone, D. B. (2011). International trends in the public and private financing of higher education. Prospects, 41(1), 157.

Saymeh, A. A., F., Ariqat, H., \& Aqel, S. (2014). Higher education and scientific research of third world countries need professional support: Case of Uganda. Education Journal, 3(4), 245-255.

Serbanica, C. M., D. L. Constantin, and G. Dragan. 2015. “University-Industry Knowledge Transfer and Network Patterns in Romania: Does Knowledge Supply Fit SMEs' Regional Profiles?” European Planning Studies 23 (2): 292-310. doi:10.1080/09654313.2013.862215.

Shipway, I. (2009).Modern portfolio theory. Trusts \& Trustees, 15(2), 66-71.

Sifuna, D. N. (2010). Some reflections on the expansion and quality of higher education in public universities in Kenya. Research in Post-Compulsory Education, 15(4), 415-425.

Sifuna, D. N. (2017). University of Nairobi: Review of the Flagship Role in Higher Education in Kenya. In Flagship Universities in Africa (pp. 197-240). Palgrave Macmillan, Cham.

Sveiby, K. E. (2001). A knowledge-based theory of the firm to guide in structure formulation. Journal of intellectual capital, 2(4), 344-358.

Tsinidou, M., Gerogiannis, V., \& Fitsilis, P. (2010). Evaluation of the factors that determine quality in higher education: an empirical study. Quality assurance in Education, 18(3), 227-244.

Turyahebwa, A., Sunday, A., \& Ssekajugo, D. (2013).Financial management practices and business performance of small and medium enterprises in western Uganda. African journal of business management, 7(38), 3875. 
UNESCO Institute for Statistics (2010).Global Education Digest 2010.Comparing Education Statistics across the World.UNESCO.

Van de Wetering, R., Mikalef, P., \& Helms, R. (2017). Driving organizational sustainability-oriented innovation capabilities: a complex adaptive systems perspective. Current opinion in environmental sustainability, 28, 71-79.

Vasi, I. B., \& King, B. G. (2012). Social movements, risk perceptions, and economic outcomes: The effect of primary and secondary stakeholder activism on firms' perceived environmental risk and financial performance. American Sociological Review, 77(4), 573-596.

Wangenge-Ouma, G. (2008) Globalisation and higher education funding policy shifts in Kenya, Journal of Higher Education Policy and Management, 30(3), 215-229, DOI: 10.1080/13600800802155010

Wangenge-Ouma, G. (2008). Higher education marketization and its discontents: the case of quality in Kenya. Higher Education, 56(4), 457-471.

Wangenge-Ouma, G. (2012). Public by Day, Private by Night: examining the private lives of Kenya's public universities. European Journal of Education, 47(2), 213-227.

World Bank Staff. (1985). World Development Report, 1985: International Capital and Economic Development. Washington DC: World Bank.

Xia, H., Wang, H., \& Ji, G. (2019). Regional Inequality and Influencing Factors of Primary PM Emissions in the Yangtze River Delta, China. Sustainability, 11(8), 2269.

Yin, R. K. (2013). Case study research: Design and methods. Sage publications.

Yu, Z., \& Xu, G. (2019, February). The Relationship between Carbon Emission and Economic Activity in the United States. In Proceedings of the 2019 5th International Conference on E-Business and Applications (pp. $114-$ 119). ACM.

Zumeta, W., Breneman, D. W., Callan, P. M., \&Finney, J. E. (2012). Financing American Higher Education in the Era of Globalization. Cambridge, MA: Harvard Education Press

Zusman, A. (2015). Challenges Facing Higher Education in the Twenty-First Century. Albany, NY: Urban Institute. 